UDC 621.891

S. Kryshtopa ${ }^{1}$, Dr. Sc. (Tech.), Assoc. Prof., orcid.org/0000-0001-7899-8817, A. Kozhevnykov ${ }^{2}$, Dr. Sc. (Tech.), Prof., orcid.org/0000-0002-2708-8917,

M. Panchuk ${ }^{1}$, Cand. Sc. (Tech.), Assoc. Prof., orcid.org/0000-0002-4898-2707,

L. Kryshtopa ${ }^{1}$, Cand. Sc. (Tech.), Assoc. Prof., orcid.org/0000-0002-5274-0217
DOI: $10.29202 /$ nvngu/2018-3/10

1 - Ivano-Frankivsk National Technical University of Oil and Gas, Ivano-Frankivsk, Ukraine, e-mail: auto.ifntung@ukr. net; 24berkyt@rambler.ru; retes@mail.ru

2 - National Mining University, Dnipro, Ukraine, e-mail: AAK2@ua.fm

\title{
INFLUENCE OF TRIBOELECTRIC PROCESSES ON FRICTION CHARACTERISTICS OF BRAKE UNITS OF TECHNOLOGICAL TRANSPORT
}

Purpose. To establish patterns of changing of friction properties at surface layers of metal-polymeric friction couples which are in the process of mechanical, thermal and electrical interactions in friction units of braking devices based on triboelectric phenomena.

Methodology. Experimental research studies of triboelectric processes were performed on specially created laboratory stand that simulated band-block brake of technological transport and serial universal brake test model KI-8964 which allowed exploring metal-polymeric friction couples of drum-block and disc brakes. Electric current measurement was carried out using nanoampermeter F-195, potential difference was measured using the analogue-digital converter USB Oscilloscope II. The number of experiments was enough to get results with confidence probability of 0.95 .

Findings. As a result of research experiments on properties of metal-polymeric friction couples of braking devices in laboratory and operating conditions during triboelectric interaction the following laws of change were established: values of potential difference of friction couples "grey cast iron - polymers" of drum-block and band-block brakes with regard to surface temperatures linings and specific loadings; dynamic friction coefficient with regard to circulating heat and tribocurrents; braking torques created by individual friction units and total braking torques with regard to changing of generated tribocurrents in contact of belayed structures "metal - polymer".

Originality. Scientific research studies on metal-polymeric friction couples can extend the database of triboelectric processes in braking devices. As a result of wear-friction properties research on metal-polymeric friction couples of braking devices in laboratory and operating conditions at nano-, micro- and millilevels there were established patterns of change in thermal stimulated bit currents and electric potentials in friction couple contact with regard to interaction time, surface temperature and specific loads, dynamic friction coefficients and value of braking torque generated from trybocurrents.

Practical value. The results allow optimizing the management of wear-friction properties and thermal state of brake unites.

Keywords: metal-polymer friction couples, drum-block brake, band-block brake, tribosystems, triboelectric processes

Introduction. The problem of friction elucidation of mechanisms of interaction is still far from a final solution. One of the reasons is the fact that in the process of friction due to electrical phenomena which occur in friction contact of metal-polymeric triboconjugations, there are substantial changes in the properties of the metal-polymeric surface layers, which significantly affects their tribological properties. A significant number of scientists' works has been dedicated to research on triboelectric phenomena of metal-polymeric friction couples of braking devices, but many of them provide contradictory information and a number of triboelectric friction interaction issues are left unattended. Specifically, mechanisms of influence of triboelectric phenomena on wear-friction properties of metal-polymeric friction couple of braking devices have not been established yet. Establishing triboelectric interaction patterns of friction couples of brakes is relevant from the point of view of implementation of new methods for improving wear-friction properties of metal-polymeric friction couples of braking device.

(C) Kryshtopa S., Kozhevnykov A., Panchuk M., Kryshtopa L., 2018
Analysis of the recent research. At present time investigations of friction at the contact of two metals, metals and semiconductors are conducted quite extensively. For example, in [1] triboelectric processes are studied in terms of high-speed friction, [2] studies triboelectric processes optimization issues and in [3] triboelectric effects during drilling process is studied. Multifactor mathematical models of mechanical high-speed drilling were studied in [4] and in [5] numerical studies on hydrodynamic processes during drilling were performed.

Huge attention has been paid to studying triboelectric processes in friction couples with oil layers in work [6]. Dual electric fields which occur in contact with presence of lubricants are investigated. Triboelectric processes samples during friction of metals and composites are studied in [7]. Values of circulating tribocurrents during friction with oils and without them for different composites were established. It has been found that while using means for reducing tribocurrents, the durability of composites has doubled on average.

In [8] triboelectric processes in friction couples from homogenous steel in case of dry friction were described. 
There were analysed main causes of electrical currents occurring during cutting and friction, effects of electrical properties, geometric parameters and different cutting methods on the value of electric currents.

Wear compensating methods for steel couples of steel $40 \mathrm{X}$ by using electric phenomena for displacement of dispersed metal particles on the surface of friction contact are considered in [9]. Effect of local electrical discharges on ensuring the workableness of friction surfaces according to tough conditions of drilling equipment was investigated and optimization of technological parameters of electric spark discharges was also performed.

Considerable attention is paid to electrochemical process during friction by researchers. Thus, in [10] the investigations on electrothermomechanical wear are explained regarding electrochemical position and relations between durability and value galvanic e.m.f of metals are established. The paper reviewed the electrochemical processes that were in contact with liquids and metals and established patterns of allocation and transfer of ions and considered wear items of metal surfaces regarding their grounded and isolated state from electrochemical perspective. [11] solves the problem of finding electrical conductivity of rough contact. Dependences for determination of electrical resistance of the actual contact area were proposed. Because of complexity of determining the resistance of surface pellicles, established laws are true mainly for precious metals.

Research on triboelectric processes in pairs "polymer-polymer" and "metal-polymer" was performed much less thoroughly. In [12] they studied the electrical conductivity in metal-polymeric couples and found that the conductivity of pure polymer is low. However, with degradation, dissociation products and contamination, conductivity of polymer increases dramatically. Many works are also devoted to the mechanism of circulation of electric current through the contact above a friction pair due to the passage of electrons from the material with a lower work function to the material with greater performance and frictional contact. For example, in [13] the emission of electrons from the surfaces of solids during friction is studied. It was found that according to the work function of electron liberation from the friction surfaces it is possible to assess the condition and defects of the surface and to determine the level of surface energy. The interaction of triboelectric effect phenomena in polymer destruction during friction was studied. It is well known that during friction, destruction of polymer molecules take place creating electron emission from the surface.

Electrical properties of polymers were studied very carefully in [14]. It was found that the conductivity of the polymer increases up to two orders at presence of copper compounds while water sorption by polymer also increased conductivity of polymers by several orders. It was established that the conductivity of polymers increases by orders if the melting point is exceeded. The article contains an analytical description of circulating currents and studies the electrical polymer conductivity depending on changes in temperature and pressure.

Triboelectric phenomena in metal-polymeric friction couples significantly affect mass transfer process and composition of the boundary layer, which determine the direction and magnitude of tribocurrents. For example, in [15] influence of electrification phenomena on mass transfer processes in metal-polymeric friction couples is shown. Formation of polymer pellicles on metal surfaces and metal transferring on the surface of the polymer were studied. However, there is not any explanation of the tribo e.m.f., changes, there are only assumptions. In [16] there were studied hydrogenation processes in metal-polymeric friction couples of band-block brakes, direction of tribocurrents circulation in friction process of metal-polymeric friction couples and the work established increased wear of friction surfaces and reduced braking performance. But the experimental data in [14-17] does not always coincide with the theoretical calculations.

Unsolved aspects of the problem. It should be noted that analysis of the relevant sources indicate uncertainty of mechanisms of triboelectrization of metal-polymeric friction couples and contradictions of a significant number of well-known research results. It should be noted that the state of the surface for polymer friction linings and metal elements is characterized by different physical nature and between triboelectric processes and wear friction characteristics as metal-polymeric friction couples surface at present there are quite ambiguous, complex and contradictory relationships which significantly affect the dynamic coefficients of friction and braking moments.

The aim and objectives of the study. The aim of this work is to study the friction properties of surface layers of metal-polymer friction couples which are in the process of mechanical, thermal and electrical interaction in the friction units of brake devices taking into account the triboelectric phenomena.

To achieve the purpose, the following tasks were put:

- to explore the potential difference in friction couples of brake devices based on mechanical and thermal gradients which occur in the surface layers of friction couples;

- to understand relations between the pulse currents in the surface layers of the braking devices and temperature gradients in metal-polymer structures;

- to determine the effect on the dynamic coefficients of friction and braking torque of electrical and thermal currents on the surfaces of the friction of braking devices, changing types of contact surfaces and areas of current pulses in the transport process brake couples.

Research methodology for triboelectric processes in metal-polymer friction couples. Considering the problems of research, a brake tester model with band-block brake was designed and manufactured (Fig. 1). The stand is designed to elucidate the characteristics of electrical and thermal currents during electrothermomechanical friction. To investigate friction units of the drum-block and disk-block brakes, diagnostic braking stand KI-8964 was used. Stand model KI-8964 is designed to determine the technical condition of vehicle braking systems by measuring the brake force operation over time and forces pressing on the brake pedal.

To fix these changes in potential difference of friction couples on a personal computer, the contact surfaces were connected to the laptop (Fig. 2) through the analog-to-digital converter of PC oscilloscope USB Os- 


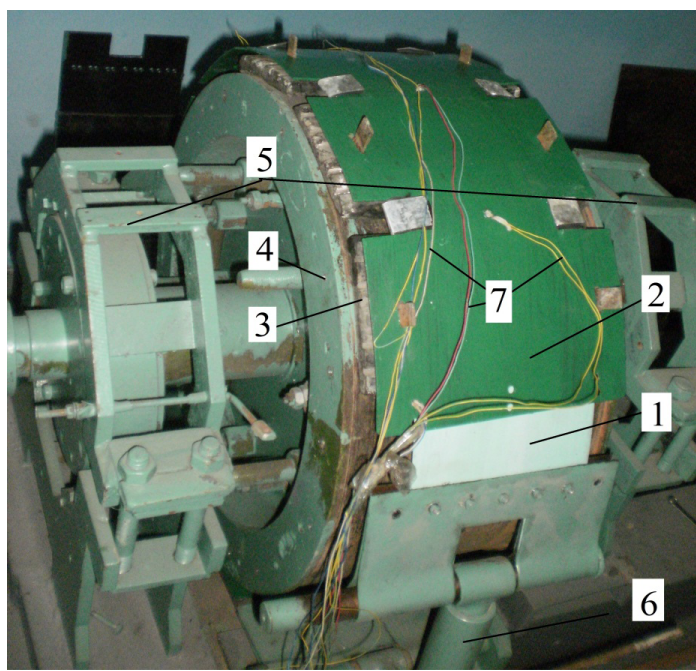

Fig. 1. General view of the improved friction units of band-block brake:

1 - the main brake band; 2 - additional brake band; 3 brake couples; 4 - brake pulley; 5 - supports the brake drum; 6 - unit of loading; 7 - electrodes

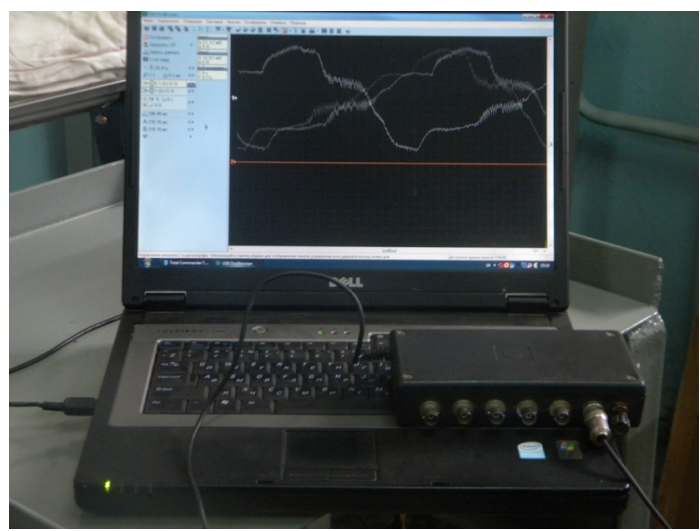

Fig. 2. Computer USB Oscilloscope

cilloscope II. The obtained value of contact potential difference of friction pairs were recorded in real time, written to a computer and processed using the computer software oscilloscope USB Oscilloscope II.

A sufficient number of tests of metal-polymeric friction couples of friction braking devices in stand conditions allows judging objectively about wear-friction processes depending on the electric current generated.

According to the above-stated, the following requirements were applied to the brake testers:

- long braking performance to assess current, potential difference and surface temperature of metal-polymeric friction couples;

- simulation of real conditions of brake friction couples with the ability to change their tribological parameters of the surface layers. tion:

The following parameters were subjected to registra-

- braking time and the number of braking actions;

- temperature and angular velocity of friction elements;

- tensions of covered and running brake band branches;
- tribocurrent forces circulating between friction couples;

- potential difference between the friction couples.

Presentation of the main research on wear friction properties of friction couples of braking devices. It is established that the contact potential difference consists of constant and pulsed (or variable) components. The constant component depends mainly on the materials of contacting surfaces and surface temperature, while the pulse component mainly depends on fluctuations of electrothermal resistance in contact and vibrations of friction surface energy. The pulse component affects the wear-friction properties of friction couples of friction units more significantly than the value of the constant component contact potential difference. Fig. 3 illustrates the dependence of the pulse potential difference of friction pairs "grey iron GI 20 - 1-43-60A code" of model brakes at $350{ }^{\circ} \mathrm{C}$, recorded with a digital oscilloscope computer USB Oscilloscope.

Surface temperature of contacting bodies significantly affects contact potential difference. If one of the bodies is heated more, electronic or ionic thermo currents will go directed to the second one. The potential difference also increases with an increasing contacting body area. Charges of contacting bodies have different signs but the same value. Fig. 4 illustrates the dependence of the constant component of the contact potential difference of brake friction couples of assembly AORS-80 from the overlap surface temperature at different specific activities. As shown in Fig. 4, for a friction couple of grey cast iron GI $20-2141$ polymer cipher brakes have a situation where a metallic friction element is charged positively according to friction units.

Increasing potential at the contact with increasing friction unit temperature is explained by the heat increases in the energy level of the electrons of the metal friction element that leads to increasing potential difference at the contact. It should be noted that in the range of $380-400^{\circ} \mathrm{C}$ there is significant growth of potential at the contact. It is explained by beginning of conversion of phenol-formaldehyde resins in the liquid phase and decrease in the electrical resistance in contact. At temperatures of $550-600{ }^{\circ} \mathrm{C}$ intensity of growth of potential reduces. This is due to a decrease in the liquid phase in contact and at temperatures of about $700{ }^{\circ} \mathrm{C}$ and above the liquid phase

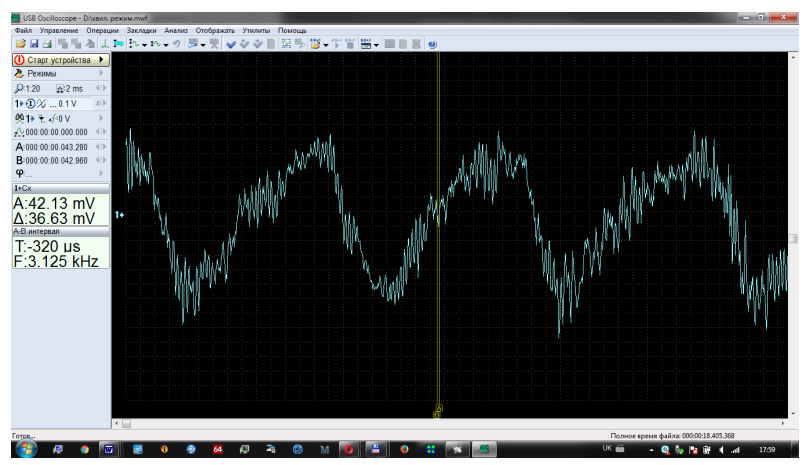

Fig. 3. Dependence of potential difference of friction couples "grey iron GI 20 - 1-43-60A code" of model of drum-block brake at $350{ }^{\circ} \mathrm{C}$ 


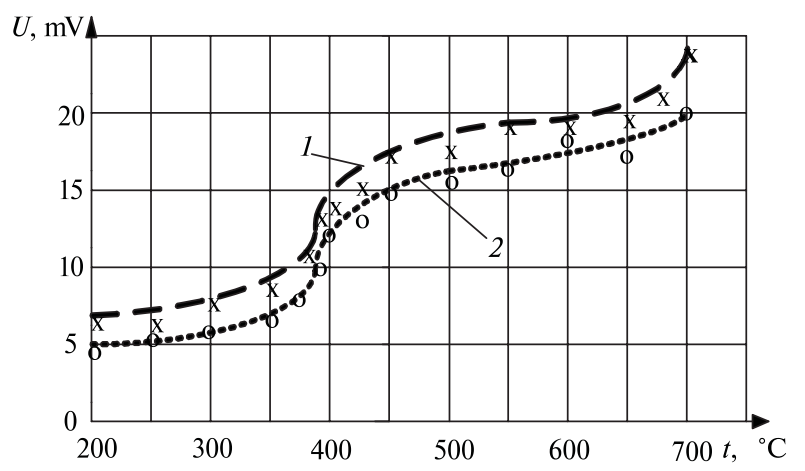

Fig. 4. Dependence of electric potential of friction couples "grey iron GI 20 - Polymer of cipher 2141" on surface temperature of the friction units:

1 - at specific loads $p=0.5 \mathrm{MPa} ; 2-$ at specific load $p=$ $=0.7 \mathrm{MPa}$

disappears (fades). It increases the electrical resistance in the contact and reduces the emission of electrons.

It was established that circulating tribocurrents lead to increase in surface temperatures in metal-polymeric friction couples, but use of tribocurrent suppression allows reducing the temperature of friction surfaces. In industrial environments there are studied patterns of temperature change for a pulley rim and friction linings regarding the number of candles lowered in standard and improved braking units of band-block brake of drilling hoist of unit AORS-80 with reduction system of tribocurrents.

Fig. 5 illustrates the patterns of changes in surface temperature of friction couples "Steel 35 XML - Retinax FK-24A" at serial band-block brakes and bandblock brake system of tribocurrents reduction of the number of cycles of braking $m$.

The values of generated currents for serial bandblock brakes are $60 \mathrm{nA}$, for band-block brake with re-

\section{Band-block brake with}

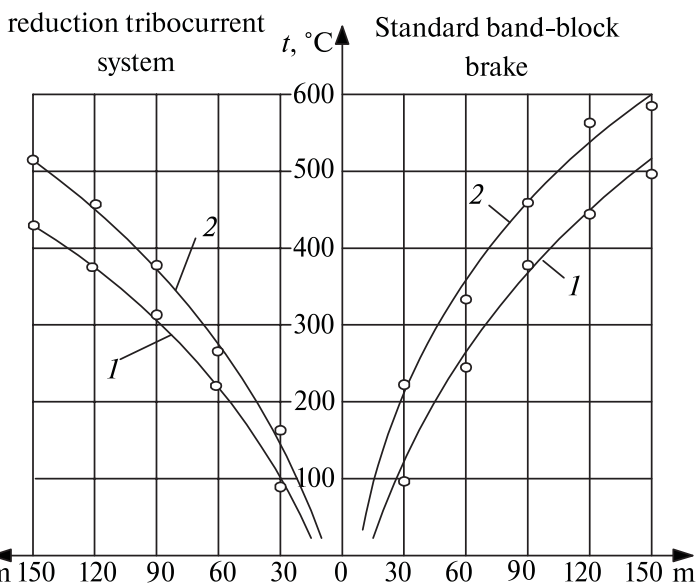

Fig. 5. Patterns of change in surface temperature of brake friction couples "Steel 35 XML - Retinax FK-24A" for standard band-block brakes and improved bandblock brake with tribocurrent reduction system depending on the number of cycles of braking $m$ and generated currents:

$1-I=10 \mathrm{nA} ; 2-I=60 \mathrm{nA}$ duction tribocurrent system - 10 nA. Maximum surface temperatures on the working surface of the brake rim pulley of improved band-block brake of unit AORS-80 with the system of tribocurrent reduction are by $14.5 \%$ lower than in standard band-block brakes and those for friction linings are by $14.3 \%$ lower.

One of the main operating parameters of band-block brakes includes tensions of running $S_{R}$ and covered brake band branches $S_{c}$, whose difference determines the friction force $\left(F_{T}=S_{c}-S_{R}\right)$. Thus, one of the brake band tensions is determined by the initial value and the second parameter is calculated. Preferably, tension of covered brake band branch $S_{c}$ is determined by Euler formula

$$
S_{c}=S_{R} e^{f \alpha} .
$$

Thus, dynamic friction coefficient is determined by such dependence

$$
f=\frac{S_{c}-S_{R}}{N}=\frac{F_{T}}{N} .
$$

Fig. 6 shows the patterns of change in dynamic friction coefficient of friction couples "Steel $34 \mathrm{~L}-$ Retinax FK-24A" and "Steel 60G - Code 6KF-59" of braking units of devices UPA-60 and A2-32 with regard to velocity of the slide and generated currents.

Total braking friction time developed by band-block brake couples depends on the radius of the brake pulley $R_{p}$ and is determined by the formula

$$
\sum_{n}^{j=1} M_{T}=\sum_{n}^{j=1} F_{T} R_{p} .
$$

Fig. 7 illustrates the patterns of changes in braking torque generated by individual brake friction units $n$ of model band-block brakes with ten friction units situated along the length of the brake band couples "Steel 35 XML - Retinax FK-16L" with regard to potential difference.

It has been established that in the range of acceptable temperature, the values of braking torques in suppress-

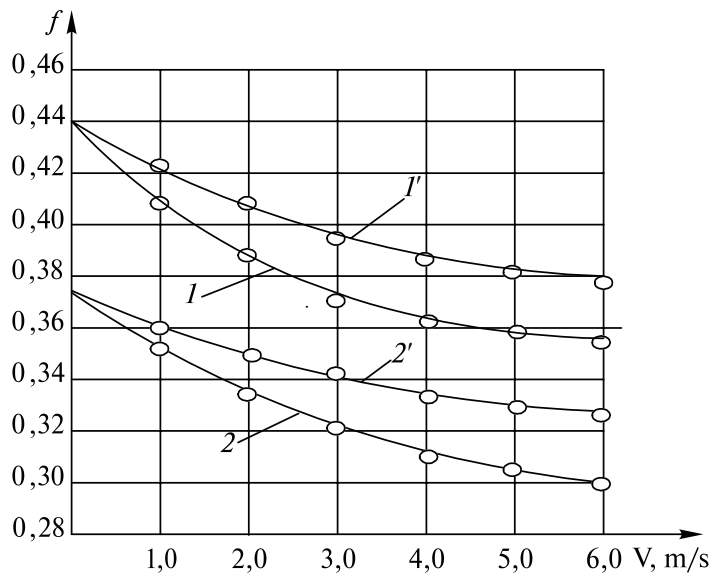

Fig. 6. Laws of dynamic friction coefficient change in friction couples "Steel 60g - code 6KF-59" (1) and "Steel 34 L - Retinax FC-24A" (2) of brake devices with regard to velocity and currents generated by the depolarization device:

$1-I=70 \mathrm{nA} ; 1^{\prime}-I=15 \mathrm{nA} ; 2-I=60 \mathrm{nA} ; 2^{\prime}-I=10 \mathrm{nA}$ 


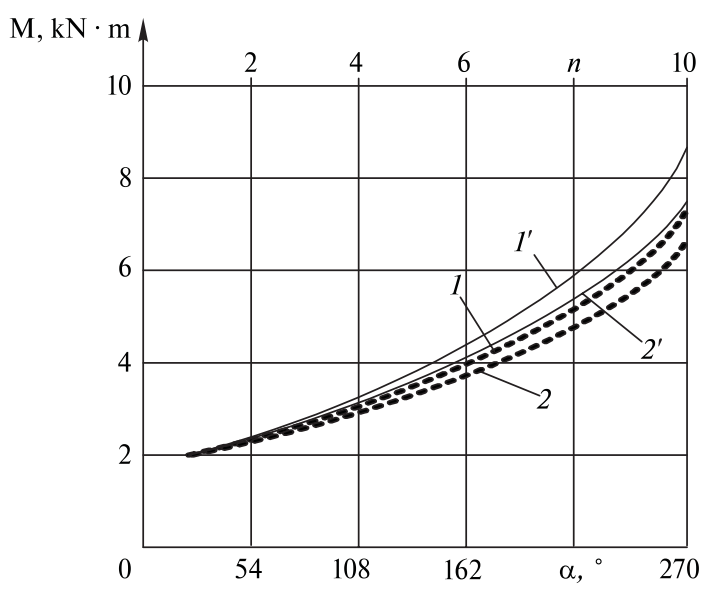

Fig. 7. Patterns of braking torque changes generated by individual brake friction units $n$ of band-block brakes with ten friction units situated along the length of the brake band couples "Steel 35 XML - Retinax FK$16 L$ " with a device lowering tribocurrents:

$1,1^{\prime}-$ at the surface temperatures of $150^{\circ} \mathrm{C}$ and potential difference 20 and $5 \mathrm{mV} ; 2,2^{\prime}$ - at the surface temperatures of $350^{\circ} \mathrm{C}$ and potential difference 15 and $3 \mathrm{mV}$

ing of tribocurrents points are on average by $5-10 \%$ more than in standard braking devices. The braking torque generated by each individual polymer brake friction unit during their contact-pulse interaction with metal worktop brake pulley is variable in nature due to changes in its switching components (dynamic friction coefficient, normal forces and friction forces).

One of the main operating parameters of friction couples is the intensity of surface wear. Fig. 8 illustrates the patterns of changes in linear wear of working surfaces of friction units of band-block brakes of metalpolymeric friction couples "Steel $34 \mathrm{~L}$ - Retinax FK24A" of the unit APRS-50KAM for standard brake and while using a tribocurrent suppression device.

Research studies on intensity wear of friction unit surfaces were performed for standard brakes without using tribocurrent reduction and with using a suppression device for tribocurrents at different values of current electrification.

Investigations were done at three hundred cyclic loadings for the tension of running band branch $S=800$ and $S=400 \mathrm{~N}$ for ten friction units.

Linear wear of friction surfaces of friction units for improved design of band-block brakes with tribocurrent suppression system is on average by $20-30 \%$ less than surface wear of friction units for standard construction of the brake.

Scientific research results of triboelectric processes in metal-polymeric friction couples. As a result of research on the wear friction properties of metal-polymeric friction couples of braking devices in laboratory and operating conditions during triboelectric interaction, the following changes were established:

- stimulated thermal currents generated on the surfaces of double layer structures depending on frictional interaction time and temperature of surface friction couples;
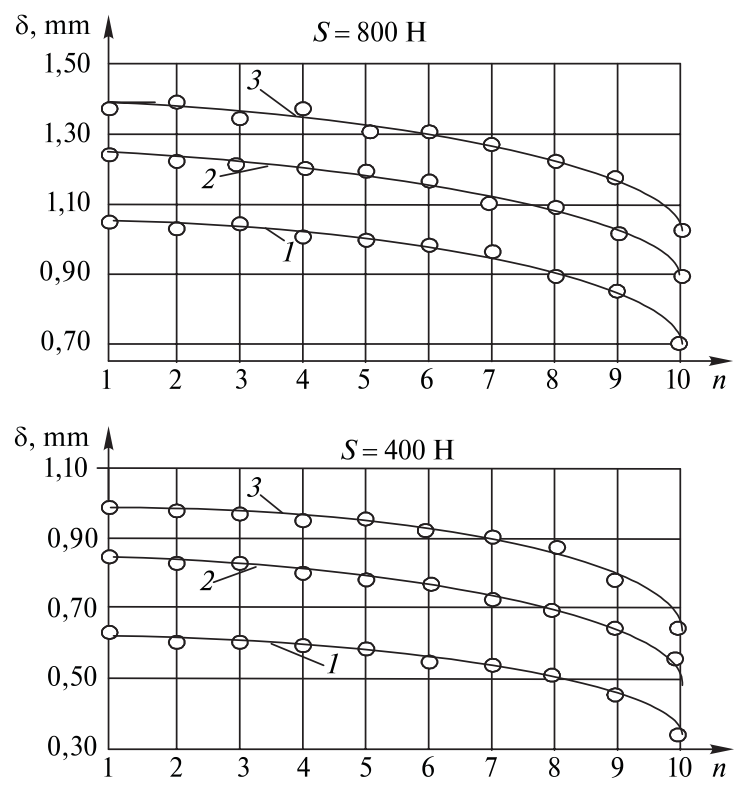

Fig. 8. Patterns of line wear changing of friction unit surfaces of a model of band-block brakes for the tension of running band branch $S=800 \mathrm{~N}$ and $S=400 \mathrm{~N}$ :

$1-I=70 \mathrm{nA}$ (standard friction unit); $2-I=50 \mathrm{nA} ; 3-$ $I=25 \mathrm{nA}$

- electric potential in contact of friction couples depending on friction engagement time, surface temperature and specific loadings;

- surface temperatures above and below acceptable temperatures for polymer material to cover potential difference and work surfaces of metal-polymeric friction couples depending on pulse unit loads during electrothermomechanical friction;

- dynamic friction coefficients of brake pulleys and friction units and brake moments of standard and improved brakes with tribocurrent reduction device for technological units;

- wear of surface friction units with regard to electrical and thermal currents on the friction surfaces of braking devices of technological transport.

There was established influence of design features of the rim of the pulley on tribocurrent circulation in it and, as a result, the origin, on evolution and distribution of a crack network in areas of maximum thermal stresses.

As a result of research experiments, it has been found that during triboelectric interaction the intensity of friction torque changes at band-block brake and drum-block brake of technological units depends on the pulse of uneven distribution of normal forces accompanied by the simultaneous formation of different types of contacts with variable energy activity causing an instant switching of pulse currents in circuits of metal-polymeric friction couples in case of abrupt pulse loading change of their items.

Practical recommendations. The investigations can be used to improve the design and operational parameters of braking devices of technological transport, design of brakes for various purposes, assessment of operational parameters of braking devices. It radically reduces terms of creation of new designs and braking devices and it can select the most effective technical solutions at the early design stage. 
Conclusions and prospects of development. As a result of research on friction properties of metal-polymeric friction couples of brake devices in laboratory and operating conditions during triboelectric interaction patterns of change were established for: values of potential difference of friction couples "metal - polymers" of drumblock brake friction units depending on the surface temperature and specific loadings; circulating heat tribocurrents and dynamic friction coefficient; braking torque generated by tribocurrents in contact of double layer structures "metal - polymer".

The obtained results allow optimizing the management of wear friction properties and thermal state of brake assemblies. Further studies can be related to more detailed study of triboelectric effects on the wear friction of surfaces of brake devices.

\section{References.}

1. Sorokatyi, R. V. and Dykha, A. V., 2015. Analysis of Processes of Tribodamages under the Conditions of High-Speed Friction. Journal of Friction and Wear, 5, pp. 422-428.

2. Shatskyi, I., Ropyak, L. and Makoviichuk, M., 2016. Strength Optimization of a Two-Layer Coating for the Particular Local Loading Conditions. Strength of Materials, 48(5), pp. 726-730.

3. Dreus, A. Yu., Kozhevnykov, A.A., Sudakov, A. K. and Vakhalin, Yu.N., 2016. Study on Thermal Strength Reduction of Rock Formation in the Diamond Core of Drilling Process Using Pulse Flushing Mode. Naukovyi Visnyk Natsionalnoho Hirnychoho Universytetu, 3, pp. 5-10.

4. Pivnyak, G., Bondarenko, V., Kovalevs'ka, I. and Illiashov, M., 2013. Preface. Annual Scientific-Technical Colletion - Mining of Mineral Deposits 2013. London, United Kingdom: CRC Press, Taylor \& Francis Group. DOI: $10.1201 / \mathrm{b} 16354$.

5. Dreus, A., Lysenko, K., Kozhevnykov, A. and Liu, B., 2017. Modeling hydrodynamics of the flushing fluid intermittent flow in the hydraulic system of the diamond bit. Mining of Mineral Deposits, 11(2), pp. 84-90. DOI:10.15407/mining 11.02.084.

6. Mikosyanchyk, O., Mnatsakanov, R., Zaporozhets, A. and Kostynik, R., 2016. Influence of the nature of boundary lubricating layers on adhesion component of friction coefficient under rolling conditions. Eastern European Journal of Enterprise Technologies, 4(1(82)), pp. 24-31.

7. Lutsak, D., Prysyazhnyuk, P., Karpash, M., Pylypiv, V. and Kotsyubynsky, V., 2016. Formation of structure and properties of composite coatings TiB2TiC-Steel obtained by overlapping of electric-arc surfacing and self-propagating higherature synthesis. Metallofizika i Noveishie Tekhnologii, 38(9), pp. 1265-1278.

8. Hang, Y., Yur, J. and Chou, H., 2006. Trib-electrification Mechanisms for Self Matedcarbon Steels in Dry Severe Wear Process. Wear [pdf], 260(11-12), pp. 12091216. Available at: <http://drr.lib.ksu.edu.tw/bitstream/98 7654321/16878/1/\%C3\%A9\%E2\%84\%A2\%E2\%80\%9E \% $3 \%$ A9\% C2\%A0\%20\% C3\%A7\% C2\%A2\% C2\%BCwear4.pdf $>$ [Accessed 11 July 2017].

9. Kryshtopa, S., Petryna, D., Bogatchuk, I., Prunko, I. and Melnyk, V., 2017. Surface Hardening of 40KH Steel by Electric-Spark Alloying. Materials Science, 53(3), pp. $351-358$.

10. Volchenko, A.I., Volchenko, N.A. and Dzhavadov, M. Ya., 2014. Electro Mechanics Wear and Destruction of Brake Wheel Rims of Drilling Hoists (part 2). Problems of Friction and Wear: Collected Scientific Engineering Papers, 3, pp. 4-17.

11. Mamedov, R.K., 2013. Contacts of Metal-Semiconductor with Electric Field of Spots. Baku: State University. 12. Kryshtopa, S., Kryshtopa, L., Bogatchuk, I., Prunko, I. and Melnyk, V., 2017. Examining the effect of triboelectric phenomena on wear-friction properties of metal-polymeric frictional couples. Eastern European Journal of Enterprise Technologies, 1(5(85)), pp. 40-45. 13. Kindrachuk, M.V., Volchenko, N.A. and Volchenko, D.A., 2013. Wear of Friction Protective Straps at Contact-Impulsive Co-operation of Metal Polymer Friction Pairs of Band-Block Brake. Problems of Friction and Wear: Collected Scientific Engineering Papers, 2, pp. 4-19. 14. Volchenko, A. I., Kindrachuk, M.V. and Volchenko, D.A., 2015. Tribology: Electrothermomechanic Bases, Analysis and Synthesis at Nano-, Mikro- and Millilevels and Technical Applications: textbook for higher education institutes. Kyiv-Krasnodar.

15. Janahmadov, A. K., Aliev, A. M., Volchenko, A. I. and Javadov, M.Y., 2013. Band-block brake with conductive cooling. In: SRI researcher notes "Geotechnological Problems of Oil, Gas and Chemistry”, Baku, pp. 113-119.

16. Pashayev, A. M., Janahmadov, A.K., Dyshin, O. A. and Javadov, M.Y., 2013. The Multi-Fractal Analysis of Fatigue Facture under Friction Process. Journal of science and applied engineering, 1, pp. 112-116.

17. Bondarenko, V., Kovalevs'ka, I. and Fomychov, V., 2012. Features of carrying out experiment using finite-element methodat multivariate calculation of mine massif combined support system. Geomechanical Processes During Underground Mining, pp. 7-13. DOI:10.1201/b13157-3.

\section{Вплив трибоелектричних процесів на фрикційні характеристики гальмівних вузлів технологічного транспорту}

\section{С. I. Криштопа ${ }^{1}$, А. О. Кожевников ${ }^{2}$, М. В. Панчук ${ }^{1}$, Л. I. Kpuштопа ${ }^{1}$}

1 - Івано-Франківський національний технічний університет нафти і газу, м. Івано-Франківськ, Україна, e-mail: rettes@mail.ru; 24berkyt@rambler.ru; auto.ifntung@ukr.net 2 - Державний вищий навчальний заклад „Національний гірничий університет”, м. Дніпро, Україна, e-mail: AAK2@ua.fm

Мета. Встановлення закономірностей зміни фрикційних властивостей поверхневих шарів металополімерних пар тертя, що перебувають у процесі механічної, теплової та електричної взаємодії, у фрикційних вузлах гальмівних пристроїв з урахуванням трибоелектричних явищ.

Методика. Експериментальні дослідження трибоелектричних процесів були проведені на спеціально створеному лабораторному стенді, що моделював стрічково-колодкове гальмо технологічного тран- 
спорту та на серійному універсальному гальмівному стенді моделі КИ-8964, що дозволяв досліджувати металополімерні пари тертя барабанно-колодкових і дискових гальм. Вимірювання трибострумів здійснювалось за допомогою наноамперметра Ф-195, а різниця потенціалів - за допомогою аналого-цифрового перетворювача USB Oscilloscope II. Кількість проведених експериментів була достатня для отримання результатів із довірчою ймовірністю 0,95 .

Результати. У результаті проведених досліджень фрикційних властивостей металополімерних пар тертя гальмівних пристроїв у лабораторних і експлуатаційних умовах під час трибоелектричної взаємодії встановлені закономірності зміни: величини контактної різниці потенціалів пар тертя „сірий чавун - полімери“ барабанно-колодкових і стрічково-колодкових гальм від поверхневої температури накладок і питомих навантажень; динамічного коефіцієнта тертя від величини циркулюючих теплових і трибострумів; величини гальмівних моментів, що створюються окремими фрикційними накладками та сумарних гальмівних моментів від зміни генерованих трибострумів у контакті двошарових структур „метал - полімер“.

Наукова новизна. Проведені дослідження трибоелектричних явищ у металополімерних парах тертя дозволяють розширити базу даних щодо трибоелектричних процесів у гальмівних пристроях. У peзультаті проведених досліджень знософрикційних властивостей металополімерних пар тертя на нано-, мікро- й мілірівнях встановлені закономірності зміни термостимульованих розрядних струмів i електричних потенціалів у контакті фрикційних пар від часу фрикційної взаємодії, поверхневої температури накладок і питомих навантажень, динамічних коефіцієнтів тертя й гальмівних моментів від величин генерованих трибострумів.

Практична значимість. Одержані результати дозволяють оптимізувати керування знософрикційними властивостями та тепловим станом гальмівних вузлів.

Ключові слова: металополімерні пари тертя, барабанно-колодкове гальмо, стрічково-колодкове гальмо, трибосистема, трибоелектричні процеси

\section{Влияние трибоэлектрических процессов на фрикционные характеристики тормозных узлов технологического транспорта}

\section{С. И. Криштопа ${ }^{1}$, А.А. Кожевников ${ }^{2}$, М. В. Панчук ${ }^{1}$, Л. И. Криштопа ${ }^{1}$}

1 - Ивано-Франковский национальный технический университет нефти и газу, г. Ивано-Франковск, Украина, e-mail: rettes@mail.ru; 24berkyt@rambler.ru; auto.ifntung@ ukr.net

2 - Государственное высшее учебное заведение „Национальный горный университет ”, г. Днепр, Украина, e-mail: AAK2@ua.fm

Цель. Установление закономерностей изменения фрикционных свойств поверхностных слоев ме- таллополимерных пар трения, которые находятся в процессе механического, теплового и электрического взаимодействия, во фрикционных узлах тормозных устройств с учетом трибоелектричных явлений.

Методика. Экспериментальные исследования трибоелектрических процессов были проведены на специально созданном лабораторном стенде, моделировавшем ленточно-колодочный тормоз технологического транспорта и на серийном универсальном тормозном стенде модели КИ-8964, позволяющем исследовать металлополимерные пары трения барабанно-колодочных и дисковых тормозов. Измерение триботоков осуществлялось с помощью наноамперметра Ф-195, а разность потенциалов - с помощью аналого-цифрового преобразователя USB Oscilloscope II. Количество проведенных экспериментов было достаточным для получения результатов с доверительной вероятностью 0,95.

Результаты. В результате проведенных исследований фрикционных свойств металлополимерных пар трения тормозных устройств в лабораторных и эксплуатационных условиях при трибоэлектрическом взаимодействии установлены закономерности изменения: величины контактной разности потенциалов пар трения „серый чугун - полимеры“ барабанно-колодочных и ленточно-колодочных тормозов от поверхностной температуры накладок и удельных нагрузок; динамического коэффициента трения от величины циркулирующих тепловых и триботоков; величины тормозных моментов, создаваемых отдельными фрикционными накладками и суммарных тормозных моментов от изменения генерируемых триботоков в контакте двухслойных структур „металл - полимер“.

Научная новизна. Проведенные исследования трибоэлектрических явлений в металлополимерных парах трения позволяют расширить базу данных по трибоэлектрическим процессам в тормозных устройствах технологического транспорта. В результате проведенных исследований износофрикционных свойств металлополимерных пар трения на нано-, микро- и миллиуровнях установлены закономерности изменения термостимулированных разрядных токов и электрических потенциалов в контакте фрикционных пар от времени фрикционного взаимодействия, поверхностной температуры накладок и удельных нагрузок, динамических коэффициентов трения и тормозных моментов от величин генерируемых во время фрикционного взаимодействия триботоков.

Практическая значимость. Полученные результаты позволяют оптимизировать управление износофрикционными свойствами и тепловым состоянием тормозных узлов технологического транспорта.

Ключевые слова: металлополимерные пары трения, барабанно-колодочный тормоз, ленточно-колодочный тормоз, трибосистемы, трибоэлектрические процессы

Рекомендовано до публікації докт. техн. наук Д. Ю. Петриною. Дата надходження рукопису 08.04.17. 